\title{
PENINGKATAN HASIL BELAJAR MATERI PERSAMAAN KUADRAT MELALUI MODEL PEMBELAJARAN THINK PAIR SHAREBERBANTUAN KOMPUTERPADA SISWA KELAS IXB SMP NEGERI 26 SEMARANG
}

\author{
Rudi Marwanto \\ SMPN 26 Semarang \\ parikesita26@gmail.com
}

Received :29/10/2019

Accepted :29/01/2020

Published : 31/01/2020

\begin{abstract}
The background of this study is because there are many students that do not have the will and the ability to study mathematics. Therefore, they think that math is a difficult subject. The main cause of this difficulty is the assumption that mathematics is not useful and can't be applied in everyday life. The aim of this study is to know whether (1) Think Pair Share model assisted with computer can increase the learning outcomes of the students IXB SMP Negeri 26 Semarang (2) Think Pair Share model assisted with computer can increase the learning activity of the students IXB SMP Negeri 26 Semarang. his study is a classroom action research in two cycles using comparative descriptive method. We compared the average value of each cycle. The result of cycle I indicated that the average is 65,32 with the percentage of classical mastery level is $52 \%$. On cycle II, the average is 76,13 with the percentage of classical mastery level is $87 \%$. Moreover, on cycle I, there are $66 \%$ of students which include in medium category. This increased to $76 \%$ which include in high category
\end{abstract}

Keywords:computer, learning outcome, quadratic equation, Think pair share.

\begin{abstract}
Abstrak
Penelitian ini dilatar belakangi banyak siswa yang kurang memiliki kemampuan dan kemauan belajar, sehingga belajar merupakan sesuatu yang sulit dan membosankan. Salah satu sebab kebosanan, dan kesulitan siswa terhadap pelajaran matematika disebabkan anggapan ketidakgunaan pelajaran matematika dalam kehidupan sehari-hari. Tujuan penulisan karya ilmiah ini adalah (1) untuk mengetahui apakah model pembelajaran Think Pair Share berbantuan komputer dapat meningkatkan hasil belajar materi Persamaan Kuadrat siswa kelas IXB SMP Negeri 26 Semarang (2) untuk mengetahui apakah model pembelajaran Think Pair Share berbantuan komputer dapat meningkatkan keaktifan siswa kelas IXB SMP Negeri 26 Semarang Semester I Tahun Pelajaran 2019/2020.Penelitian ini merupakan penelitian tindakan kelas dengan metode analisis data, menggunakan metode deskriptif komparatif yaitu membandingkan rata-rata nilai tiap siklus dengan indikator kinerjanya. Pelaksanaan penelitian dilakukan dalam dua siklus. Hasil refleksi siklus pertama digunakan untuk menyempurnakan siklus kedua. Hasil penelitian menunjukkan bahwa pada siklus I rata-rata kelas adalah 65,32 dengan persentase ketuntasan klasikal $52 \%$. Pada siklus II rata-rata kelas adalah 76,13 dengan persentase ketuntasan $87 \%$. Keaktifan siswa setelah dilakukan Penelitian Tindakan Kelas siklus I keaktifan siswa yaitu $66 \%$ katagori cukup. kemudian pada siklus II keaktifan siswa meningkat menjadi $76 \%$ katagori tinggi.
\end{abstract}

Kata Kunci: Model pembelajaran Think Pair Share, Komputer ,Hasil belajar, Materi Persamaan Kuadrat

\section{Pendahuluan}

Matematika sebagai salah satu ilmu yang diajarkan di sekolah, baik tingkat dasar maupun menengah, mempunyai ruang lingkup materi atau bahan kajian yang berbeda-beda. Berdasarkan pengalaman guru, menyatakan bahwa dalam menyampaikan bahan ajar 
matematika kepada para siswa terdapat berbagai kesulitan khususnya yang berkaitan dengan penyelesaian suatu masalah.

Pada jenjang pendidikan dasar terdapat beberapa materi yang tidak mudah dipahami siswa jika hanya disampaikan dengan menggunakan metode ekspositori atau metode ceramah serta membuat siswa konsentrasi, dan aktif terhadap materi yang disampaikan. Padahal kondisi kelas sudah cukup baik dengan dilengkapi fasilitas yang diperlukan.

Dalam proses pembelajaran, siswa kadang bersikap pasif atau hanya menerima materi tanpa melakukan aktivitas. Sehingga ada kecenderungan siswa untuk cepat melupakan apa yang diberikan. Salah satu faktor yang menyebabkan informasi cepat dilupakan adalah faktor kelemahan otak manusia itu sendiri, karena proses belajar tersebut hanya mengandalkan indera pendengaran.

Siswa sangat berperan dalam proses pembelajaran dan berusaha secara aktif untuk mengembangkan dirinya dibawah bimbingan guru, mengingat siswa mampu menciptakan situasi kegiatan belajar yang menyenangkan. Hal itu dikarenakan siswa bukanlah objek pendidikan, melainkan subjek yang aktif dalam proses pembelajaran. (W.Gulo, 2002: 23)

Pada dasarnya setiap siswa mempunyai cara belajar yang berbeda-beda. Ada siswa yang lebih senang membaca, berdiskusi dan ada juga yang senang praktik langsung. Inilah yang sering disebut dengan gaya belajar atau learning style (Hisyam Zaini, 2007: 26). Untuk dapat membantu siswa dengan maksimal dalam belajar, maka kesenangan dalam belajar sebisa mungkin diperhatikan.

Padakehidupan sehari-hari, terdapat banyak tugas- tugas manusia yang dapat dilakukan oleh komputer. Komputer digunakan dalam berbagai bidang, antara lain bidang komunikasi, transportasi, industri, kesehatan, kesenian, pertanian bahkan dalam bidang pendidikan. Suatu kecenderungan yang dapat diamati adalah bahwa komputer merupakan media yang efektif dan efisien dalam menyampaikan pesan-pesan instruksional. Kemampuan komputer untuk berinteraksi secara cepat dan akurat, bekerja dengan cepat dan tepat, serta menyimpan data dalam jumlah besar dan aman, telah menjadikan komputer sebagai media yang cocok dan dominan di bidang pendidikan di samping media yang lain (Anderson, 1987:195).

Berdasarkan hasil ulangan harian pada materi bilangan berpangkat dan bentuk akar menunjukkan bahwa dari 31 siswa yang tuntas sesuai batas Kriteria Ketuntasan Minimal (KKM) 70 sebanyak 9 siswa yang tuntas dengan persentase $29 \%$, sedangkan yang tidak tuntas sesuai KKM sebanyak 22 siswa dengan persentase $71 \%$.. Dari data tersebut dapat disimpulkan bahwa sebagian besar siswa kelas IXB SMP Negeri 26 Semarang masih belum mencapai ketuntasan belajar. Sebagai guru menyadari sepenuhnya didalam melaksanakan pembelajaran di kelas belum memanfaatkan secara maksimal berbagai faktor yang dapat 
meningkatkan hasil belajar, khususnya pembelajaran model think phair share, mengingat selama ini hanya pembelajaran secara konvensional.

Dengan adanya model pembelajaran yang mampu menjadikan situasi proses belajar mengajar di sekolah sebagai kegiatan yang lebih mengaktifkan siswa untuk membaca dan memecahkan masalah sendiri di bawah pengawasan dan bimbingan guru yang selalu siap menolong siswa yang mempunyai kesulitan. Untuk pencapaian hasil belajar yang memuaskan, guru harus bisa memilih strategi pembelajaran yang sesuai dengan tujuan dan materi pembelajaran. Pemilihan strategi pembelajaran ini dapat dilakukan melalui kerjasama yang aktif dan kreatif antara guru dengan siswa.

Salah satu model pembelajaran aktif yang dapat digunakan guru adalah Think Pair Share (TPS) berbantuan komputer, dimana siswa melakukan aktifitas bersama pasangannya untuk menyelesaikan suatu masalah. Model ini cukup mampu untuk membantu siswa dalam meningkatkan hasil belajar dan keaktifan siswa dalam menyelesaikan masalah pembelajaran matematika.

Strategi think-pair-share (TPS) atau berpikir berpasangan berbagi adalah merupakan jenis pembelajaran kooperatif yang dirancang untuk mempengaruhi pola interaksi siswa. Strategi think-pair-share ini berkembang dari penelitian belajar kooperatif dan waktu tunggu. Pertama kali dikembangkan oleh Frang Lyman dan koleganya di Universitas Maryland sesuai yang dikutip Arend, 1997 (dalam Trianto, 2007) menyatakan bahwa think-pair-share merupakan suatu cara yang efektif untuk membuat variasi suasana pola diskusi kelas. Dengan asumsi bahwa semua resitasi atau diskusi membutuhkan pengaturan untuk mengendalikan kelas secara keseluruhan, dan prosedur yang digunakan dalam think-pair-share dapat memberi siswa lebih banyak waktu berpikir untuk merespon dan saling membantu. Guru memperkirakan hanya melengkapi penyajian singkat atau siswa membaca tugas, atau situasi yang menjadi tanda tanya. Sekarang guru menginginkan siswa mempertimbangkan lebih banyak apa yang telah dijelaskan dan dialami. Guru memilih menggunakan think-pair-share untuk membandingkan tanya jawab kelompok keseluruhan. Guru menggunakan langkahlangkah (fase) berikut :

\section{Langkah 1 : Berpikir (Thinking)}

Guru mengajukan suatu pertanyaan atau masalah yang dikaitkan dengan pelajaran, dan meminta siswa menggunakan waktu beberapa menit untuk berpikir sendiri jawaban atau masalah. Siswa membutuhkan penjelasan bahwa berbicara atau mengerjakan bukan bagian berpikir.

2. Langkah 2 : Berpasangan ( Pairing)

Selanjutnya guru meminta siswa untuk berpasangan dan mendiskusikan apa yang telah mereka peroleh. Interaksi selama waktu yang disediakan dapat menyatukan jawaban 
jika suatu pertanyaan yang diajukan atau menyatukan gagasan apabila suatu masalah khusus yang diidentifikasi. Secara normal guru memberi waktu tidak lebih dari 4 atau 5 menit untuk berpasangan.

3. Langkah 3 : Berbagi (Sharing)

Pada langkah akhir, guru meminta pasangan-pasangan untuk berbagi dengan keseluruh kelas yang telah mereka bicarakan. Hal ini efektif untuk berkeliling ruangan dari pasangan ke pasangan dan melanjutkan sampai sekitar sebagian pasangan mendapatkan kesempatan untuk melaporkan Arends, 1997; disadur Tjokrodihardjo, 2003 (dalam Trianto, 2007).

Pembelajaran berbantuan komputer berkaitan langsung dengan pemanfaatan komputer dalam proses belajar mengajar baik di dalam maupun di luar kelas, secara individu maupun secara kelompok (Suharjo, 1994:46-47). Pembelajaran berbantuan komputer dibagi menjadi 5 kelompok, yaitu (1) tutorial, (2) latih dan praktik, (3) simulasi, (4) permainan dan (5) pemecahan masalah.

\section{Metode Penelitian}

\section{a. Subjek Penelitian}

Subjek penelitian adalah siswa kelas IXB SMPN 26 Semarang, dengan jumlah 31 siswa yang terdiri dari 17 siswa putri dan 14 siswa putra.

\section{b. Tempat Penelitian}

Penelitian Tindakan Kelas dilaksanakan di Kelas IXB SMPN 26 Semarang Semester I Tahun Pelajaran 2019/2020.

\section{B. Desain Prosedur Penelitian}

Pelaksanaan penelitian tindakan kelas ini dua siklus. Ada empat tahapan yang dilaksanakan dalam penelitian tindakan kelas ini yaitu perencanaan, pelaksanaan tindakan, pengamatan dan refleksi.

Penelitian tindakan ini dilakukan sebagai upaya untuk meningkatkan hasil belajar siswa. Kegiatan penelitian tindakan dilakukan dengan melalui 2 siklus, yaitu siklus I dan siklus II. Alasan penelitian ini dibagi menjadi dua siklus adalah untuk menyesuaikan banyaknya materi agar peningkatan hasil belajar materi Persamaan Kuadrat melalui model pembelajaran Think Pair Share berbantuan komputer siswa kelas IXB SMP Negeri 26 Semarang pada setiap siklusnya lebih terlihat.

. Model dan penjelasan untuk masing-masing tahap menurut Kemmis dan Mc Taggart (Arikunto, 2008: 16) yaitu: perencanaan (planning), tindakan (acting), pengamatan (observing), dan refleksi (reflecting) seperti tampak pada desain berikut. 


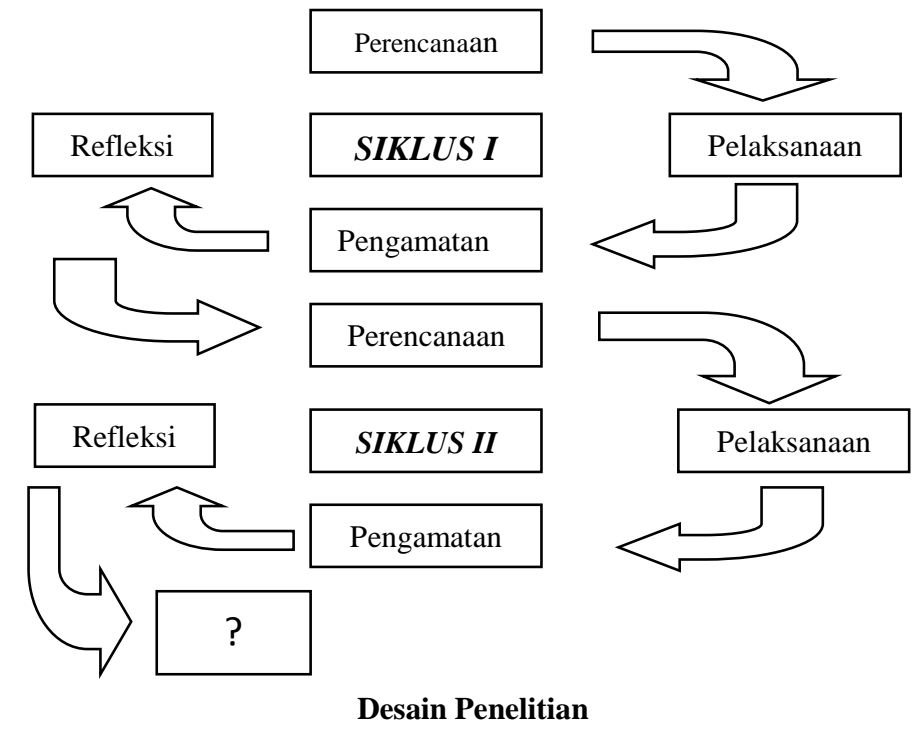

Berikut ini akan diuraikan secara singkat untuk masing-masing siklus.

\section{SIKLUS I}

1. Perencanaan

a. Identifikasi masalah dan rumusan masalah. Dalam hal ini peneliti memilih materi Persamaan Kuadrat

b. Guru dan peneliti kolaboratif membuat rencana pembelajaran yang sesuai dengan langkah-langkah pada model pembelajaran Think Pair Share (TPS)

c. Membuat soal (masalah) dan jawaban (penyelesaian) untuk evaluasi siklus I

d. Menyusun lembar kerja siswa

e. Menyusun lembar observasi

f. Menyiapkan sarana pembelajaran yang diperlukan

g. Pada hari sebelum proses pembelajaran, guru meminta siswa untuk belajar materi Persamaan Kuadrat

2. Pelaksanaan Tindakan

a. Guru menyampaikan tujuan pembelajaran/indikator yang akan dicapai

b. Guru memberikan motivasi pada siswa

c. Guru memberi petunjuk dan penjelasan mengenai cara-cara pelaksanaan mencari pasangan

d. Guru melakukan proses pembelajaran sesuai dengan rencana pembelajaran pada model pembelajaran Thing Pair Share (TPS)

e. Guru membimbing tiap-tiap pasangan yang akan menyelesaikan masalah yang diberikan

f. Guru memberikan penghargaan kepada pasangan yang lebih dulu berhasil menyelesaikan masalah

g. Guru memberikan tugas rumah (PR) sebagai bahan pemantapan materi pada siswa

h. Guru bersama siswa menarik kesimpulan

3. Pengamatan

Pengamatan dilakukan oleh observer sebagai berikut:

a. Obervasi terhadap siswa 
Kegiatan mengamati keaktifan siswa dalam pembelajaran serta kemampuan menyelesaikan soal-soal

b. Observasi terhadap guru

Kegiatan mengamati guru dalam pengelolaan model pembelajaran Think Pair Share.

\section{Refleksi}

Hasil yang diperoleh dari pengamatan dan tes evaluasi pada tindakan siklus I digunakan sebagai dasar apakah sudah memenuhi target/perlu dilakukan penyempurnaan pada strategi pembelajaran agar siklus II diperoleh hasil yang lebih baik.

\section{SIKLUS II}

a. Perencanaan

a. Identifikasi masalah dan rumusan masalah. Dalam hal ini peneliti memilih materi Persamaan Kuadrat

b. Guru dan peneliti kolaboratif membuat rencana pembelajaran yang sesuai dengan langkah-langkah pada model pembelajaran Think Pair Share (TPS)

c. Membuat soal (masalah) dan jawaban (penyelesaian) untuk evaluasi siklus II

d. Menyusun lembar kerja siswa

e. Menyusun lembar observasi

f. Menyiapkan sarana pembelajaran yang diperlukan

g. Pada hari sebelum proses pembelajaran, guru meminta siswa untuk belajar mengenai materi Persamaan Kuadrat

b. Pelaksanaan Tindakan

a. Guru menyampaikan tujuan pembelajaran/indikator yang akan dicapai

b. Guru memberikan motivasi pada siswa

c. Guru memberi petunjuk dan penjelasan mengenai cara-cara pelaksanaan mencari pasangan

d. Guru melakukan proses pembelajaran sesuai dengan rencana pembelajaran pada model pembelajaran Think Pair Share (TPS)

e. Guru membimbing tiap-tiap pasangan yang akan menyelesaikan masalah yang diberikan

f. Guru memberikan penghargaan kepada pasangan yang lebih dulu berhasil menyelesaikan masalah

g. Guru memberikan tugas rumah (PR) agar siswa lebih memahami materi dan bahan persiapan tes evaluasi

h. Guru bersama siswa menarik kesimpulan

c. Pengamatan

Pengamatan dilakukan oleh observer sebagai berikut:

1. Obervasi terhadap siswa

Kegiatan mengamati keaktifan dalam pembelajaran serta kemampuan menyelesaikan soal-soal

2. Observasi terhadap guru

Kegiatan mengamati guru dalam pengelolaan model pembelajaran Think Pair Share 


\section{d. Refleksi}

Refleksi merupakan analisis hasil pengamatan, dan evaluasi dari tahapan-tahapan pada siklus II. Diharapkan setelah 2 siklus ini kemampuan siswa dalam menyelesaikan soal dan keaktifan belajar siswa semakin meningkat

\section{Analisis Data}

1. Data keaktifan siswa

Lembar pengamatan siswa dalam proses pembelajaran dan guru dalam mengajar mencapai maksimal dengan skala penilaian:

$$
\text { Skor penilaian }=\frac{\text { jumlah item terbanyak dalam skala penilaian }}{\text { jumlah } \text { seluruh } \text { item skala penilaian }} \times 100 \%
$$

Kriteria Penilaian :

A : $81 \%-100 \%=$ Keaktifan sangat tinggi

B : $71 \%-80 \%=$ Keaktifantinggi

C : $61 \%-70 \%=$ Keaktifan cukuptinggi

D : $\quad \leq 60 \%=$ Keaktifan kurangtinggi

2. Data Hasil Belajar

Adapun rumus yang digunakan:

a) Menghitung nilai rata-rata

Untuk menghitung nilai rata-rata menggunakan rumus :

$$
\bar{x}=\frac{\sum x}{N}
$$

Keterangan:

$$
\begin{array}{ll}
\bar{x} & =\text { rata-rata nilai } \\
\sum x & =\text { jumlah seluruh nilai } \\
\mathrm{N} & =\text { Jumlah Siswa }
\end{array}
$$

b) Menghitung ketuntasan belajar

1) Ketuntasan belajar individual

Data yang diperoleh dari kemampuan siswa menyelesaikan masalah dapat ditentukan ketuntasan belajar individu menggunakan analisis deskriptif persentase dengan perhitungan:

$$
\text { Ketuntasan belajar individu }=\frac{\text { jumlah skor yang diperoleh anak }}{\text { jumlah skor total }} \times 100
$$

2) Ketuntasan belajar klasikal 
Data yang diperoleh dari kemampuan siswa menyelesaikan masalah dapat ditentukan ketuntasan belajar klasikal menggunakan analisis deskriptif persentase dengan perhitungan:

$$
\text { Ketuntasan belajar klasikal }=\frac{\text { jumlah siswa yang tuntas belajar individu }}{\text { jumlah siswa }} \times 100 \%
$$

\section{Indikator Keberhasilan}

Yang menjadi indikator keberhasilan dalam penelitian ini adalah hasil belajar materi Persamaan Kuadrat dapat meningkat, ditunjukkan rata-rata hasil belajar individual sesuai KKM adalah 70 dan persentase banyaknya siswa yang mendapat nilai $\geq 70$ ketuntasan klasikal adalah 75\%, masing-masing aspek keaktifan siswa dalam pembelajaran minimal kategori tinggi.

\section{Hasil dan Pembahasan}

\section{Deskripsi Hasil Penelitian}

\section{a. Diskripsi Kondisi Awal}

Berdasarkan tabel di atas dan grafik tersebut dapat diperoleh informasi bahwa Kriteria Ketuntasan Belajar Minimal (KKM) untuk mata pelajaran Matematika kelas IX SMPN 26 Semarang adalah 70dari 31 siswa kelas IXB yang tidak tuntas sebanyak 22 siswa (71\%), sisanya 9 siswa telah tuntas (29\%) di atas KKM. Nilai terendah yang didapatkan siswa yaitu 62 dan nilai tertinggi 78, dengan rata-rata kelas 68,90.

Dari data di atas dapat disimpulkan bahwa hasil belajar pada kondisi awal masih sangat rendah, kemudian sebagai tindak lanjut untuk meningkatkan kualitas pembelajaran Matematika, maka peneliti melakukan Penelitian Tindakan Kelas (PTK).

\section{b. Diskripsi Siklus I dan Siklus II}

\section{a. Hasil Penelitian Siklus I}

Sebagai tindak lanjut dari proses pembelajaran dan hasil belajar maka peneliti melakukan PTK dengan melakukan proses pembelajaran siklus I. Siswa bekerja sama berdiskusi bersama pasangan mereka, Beberapa diantara mereka antusias dan aktif, namun ada juga siswa yang kurang aktif dalam bekerja secara berpasangan.

Pertemuan yang kedua merupakan kelanjutan dari pertemuan pertama dimana siswa telah selesai mengerjakan LKS. Pada kegiatan pembelajaran ini, siswa diminta untuk mempresentasikan hasil diskusi mereka pada pertemuan pertama di depan kelas. Siswa masih terlihat malu-malu dan tidak terbiasa dalam mempresentasikan hasil diskusi di depan kelas, namun dengan arahan dan bimbingan peneliti akhirnya siswa menjadi lebih percaya diri dan lebih baik dalam presentasi hasil diskusi kelompok. Setelah selesai mempresentasikan hasil 
diskusi, peneliti memberikan penguatan konsep dan memberikan soal evaluasi kepada siswa. Pada siklus I telah terjadi peningkatan keaktifan siswa dalam pembelajaran Matematika materi Persamaan Kuadrat di kelas IXB. Hal ini dapat dilihat pada tabel dan grafik di bawah ini

Tabel 1. Pencapaian Keaktifan Siswa Siklus I

\begin{tabular}{|c|c|c|c|c|}
\hline No. & Indikator Perilaku Positif & Frekuensi & $\begin{array}{l}\text { Persen } \\
(\%)\end{array}$ & Keterangan \\
\hline 1 & $\begin{array}{l}\text { Siswa aktif menyelesaikan tugas } \\
\text { yang diberikan guru }\end{array}$ & 97 & $63 \%$ & \\
\hline 2 & $\begin{array}{l}\text { Siswa membantu teman lain yang } \\
\text { kesulitan menyelesaikan materi } \\
\text { persamaan kuadrat }\end{array}$ & 99 & $64 \%$ & \\
\hline 3 & $\begin{array}{l}\text { Siswa berani menyampaikan } \\
\text { pendapat atau gagasan }\end{array}$ & 100 & $65 \%$ & \\
\hline 4 & $\begin{array}{l}\text { Siswa berani mengajukan pertanyaan } \\
\text { kepada guru mengenai materi yang } \\
\text { belum dipahami }\end{array}$ & 100 & $65 \%$ & \\
\hline 5 & $\begin{array}{l}\text { Siswa memperhatikan penjelasan } \\
\text { guru atau teman }\end{array}$ & 102 & $66 \%$ & \\
\hline 6 & $\begin{array}{l}\text { Siswa menuliskan hasil kerja } \\
\text { kelompok }\end{array}$ & 102 & $66 \%$ & \\
\hline 7 & $\begin{array}{l}\text { Siswa mampu mengoperasikan } \\
\text { komputer }\end{array}$ & 109 & $70 \%$ & \\
\hline 8 & $\begin{array}{l}\text { Siswa mampu menggunakan } \\
\text { program komputer }\end{array}$ & 110 & $71 \%$ & \\
\hline & Pencapaian & 819 & $66 \%$ & Cukup \\
\hline
\end{tabular}

Hasil belajar siswa setelah dilaksanakannya siklus I dapat dilihat dari data nilai berikut ini:

Tabel 2 Hasil Tes Siklus I

\begin{tabular}{|l|l|c|}
\hline No & \multicolumn{1}{|c|}{ Uraian } & Keterangan \\
\hline 1. & Banyaknya siswa & 31 siswa \\
\hline 2. & Rata-rata Nilai & 65,32 \\
\hline 3. & Nilai tertinggi & 100 \\
\hline 4. & Nilai terendah & 45 \\
\hline 5. & Banyak siswa yang mendapat nilai $\geq 70$ & 16 \\
\hline 6. & Persentase siswa yang mendapat nilai $\geq 70$ & $52 \%$ \\
\hline 7. & Banyak siswa yang mendapat nilai $<70$ & 15 \\
\hline 8. & Persentase siswa yang mendapat nilai $<70$ & $48 \%$ \\
\hline
\end{tabular}

Hasil tes siklus I diperoleh nilai tertinggi 100, nilai terendah 45 nilai rata-rata kelas adalah 65,32 siswa yang mendapat nilai lebih dari 70 sebanyak 16 siswa (52\%), sedangkan siswa yang mendapat nilai kurang dari 70 sebanyak 15 siswa (48\%). Secara visual dapat 
disajikan pada diagram batang tentang rata - rata hasil belajar dan rata-rata secara klasikal pada grafik 1 berikut ini.

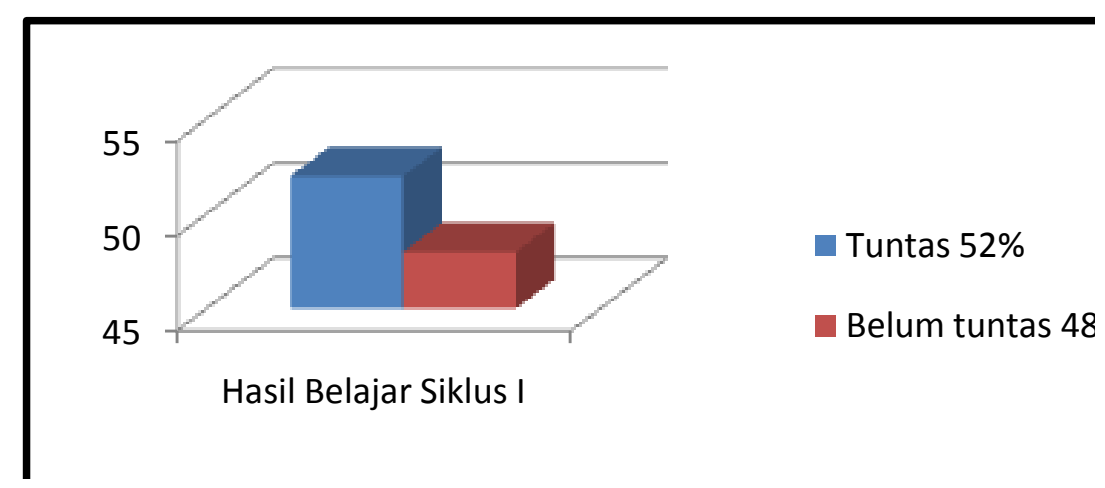

Grafik 1. Hasil Belajar Siklus I

Dari data tersebut dapat disimpulkan bahwa penguasaan materi sudah meningkat, meskipun belum optimal, yaitu 16 siswa dari 31 siswa (52\%) sudah mencapai tuntas namun belum sesuai indikator keberhasil minimal 75\%, maka kegiatan penelitian dilanjutkan pada siklus II.

Berikut dokumentasi model pembelajaran Think Pair Share berbantuan komputer siklus I, seperti tampak pada gambar 1 .

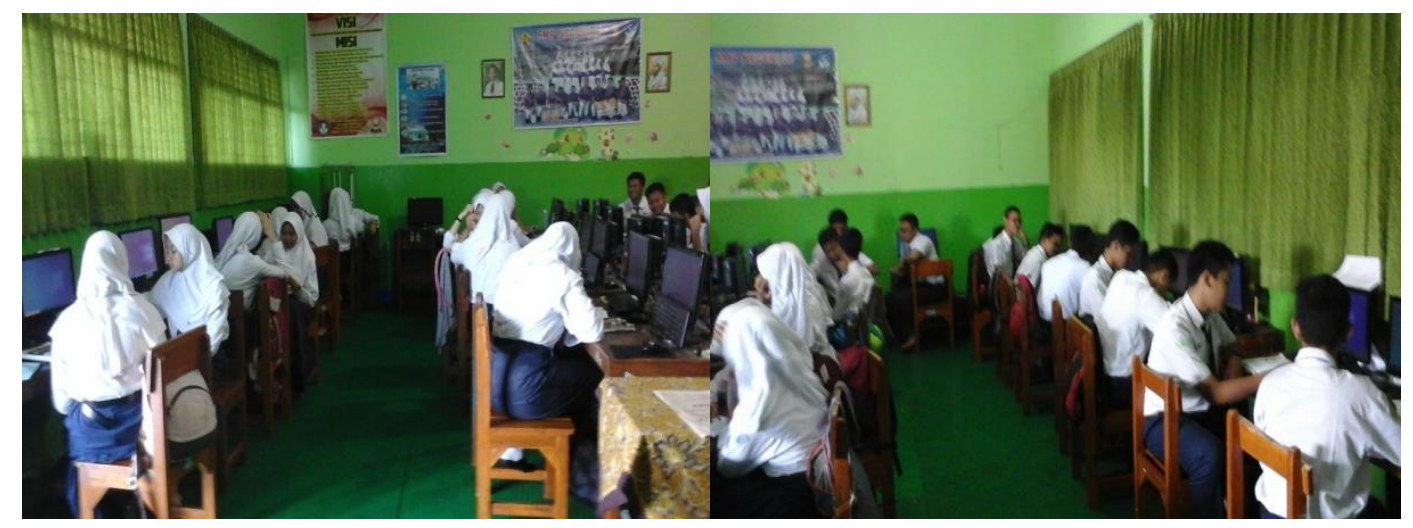

Gambar 1 Pembelajaran Siklus I

\section{b. Hasil Penelitian Siklus II}

Siklus II dilaksanakan sebagai tindak lanjut dari proses pembelajaran dan hasil belajar pada siklus I yang belum optimal. Pada proses pembelajaran ini siswa bekerja sama berdiskusi secara berpasangan. Pada siklus II ini mereka antusias dan aktif. Dalam melakukan pengamatan proses, peneliti dibantu oleh teman sejawat sebagai observer. Pada kegiatan pembelajaran ini, kegiatan yang dilakukan siswa adalah mempresentasikan hasil diskusi mereka pada pertemuan pertama di depan kelas. 
Pada siklus II ini siswa telah terlihat percaya diri. Hal ini dimungkinkan siswa telah terbiasa dalam mempresentasikan hasil diskusi di depan kelas. Setelah selesai mempresentasikan hasil diskusi, peneliti memberikan penguatan konsep, memberikan soal evaluasi, dan membahas soal evaluasi bersama serta menyimpulkan materi pembelajaran.

Pada siklus II peningkatan proses pembelajaran mengenai motivasi siswa dalam pembelajaran matematika tentang materi persamaan kuadrat cukup memuaskan. Hal ini dapat dilihat tabel dan grafik di bawah ini

Tabel 3. Pencapaian Keaktifan Siswa Siklus II

\begin{tabular}{|c|c|c|c|c|}
\hline No. & Indikator Perilaku Positif & Frekuensi & Persen $(\%)$ & Keterangan \\
\hline 1 & $\begin{array}{l}\text { Siswa aktif menyelesaikan tugas } \\
\text { yang diberikan guru }\end{array}$ & 113 & $73 \%$ & \\
\hline 2 & $\begin{array}{l}\text { Siswa membantu teman lain yang } \\
\text { kesulitan menyelesaikan materi } \\
\text { persamaan kuadrat }\end{array}$ & 113 & $73 \%$ & \\
\hline 3 & $\begin{array}{l}\text { Siswa berani menyampaikan } \\
\text { pendapat atau gagasan }\end{array}$ & 116 & $75 \%$ & \\
\hline 4 & $\begin{array}{l}\text { Siswa berani mengajukan } \\
\text { pertanyaan kepada guru mengenai } \\
\text { materi yang belum dipahami }\end{array}$ & 116 & $75 \%$ & \\
\hline 5 & $\begin{array}{l}\text { Siswa memperhatikan penjelasan } \\
\text { guru atau teman }\end{array}$ & 118 & $76 \%$ & \\
\hline 6 & $\begin{array}{l}\text { Siswa menuliskan hasil kerja } \\
\text { kelompok }\end{array}$ & 120 & $77 \%$ & \\
\hline 7 & $\begin{array}{l}\text { Siswa mampu mengoperasikan } \\
\text { komputer }\end{array}$ & 123 & $79 \%$ & \\
\hline 8 & $\begin{array}{l}\text { Siswa mampu menggunakan } \\
\text { program komputer }\end{array}$ & 126 & $81 \%$ & \\
\hline & Pencapaian & 945 & $76 \%$ & Tinggi \\
\hline
\end{tabular}

Hasil belajar siswa setelah dilaksanakannya siklus II dapat dilihat dari datanilai berikut ini:

Tabel 4 Hasil Tes Siklus II

\begin{tabular}{|c|l|l|}
\hline No & \multicolumn{1}{|c|}{ Uraian } & Keterangan \\
\hline 1 & Banyaknya siswa & 31 siswa \\
\hline 2 & Rata-rata Nilai & 76,13 \\
\hline 3 & Nilai tertinggi & 100 \\
\hline 4 & Nilai terendah & 65 \\
\hline 5 & Banyak siswa yang mendapat nilai $\geq 70$ & 27 \\
\hline 6 & Persentase siswa yang mendapat nilai $\geq 70$ & $87 \%$ \\
\hline 7 & Banyak siswa yang mendapat nilai $<70$ & 4 \\
\hline 8 & Persentase siswa yang mendapat nilai $<70$ & $13 \%$ \\
\hline
\end{tabular}

Hasil tes siklus II diperoleh nilai tertinggi 100, nilai terendah 65 nilai rata-rata kelas adalah 76,13, siswa yang mendapat nilai lebih dari 70 sebanyak 27 siswa (87\%), sedangkan 
siswa yang mendapat nilai kurang dari 70 sebanyak 4 siswa (13\%). Secara visual dapat disajikan pada diagram batang tentang rata - rata hasil belajar dan rata-rata secara klasikal pada grafik 1 berikut ini.

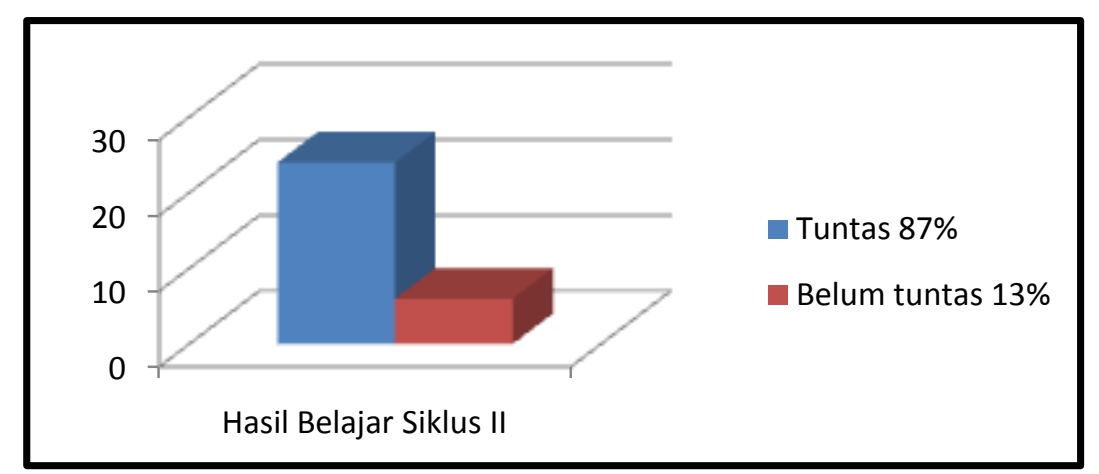

Grafik 2. Hasil Belajar Siklus II

Dari data tersebut dapat disimpulkan bahwa penguasaan materi sudah mengalami peningkatan bila dibandingkan sebelumnya. Pada siklus II ketuntasan belajar klasikal telah mencapai $87 \%$ sehingga peneliti sudah tidak melakukan pembelajaran siklus III.

Berikut dokumentasi model pembelajaran Think Pair Share berbantuan komputer siklus II, seperti tampak pada gambar 2.

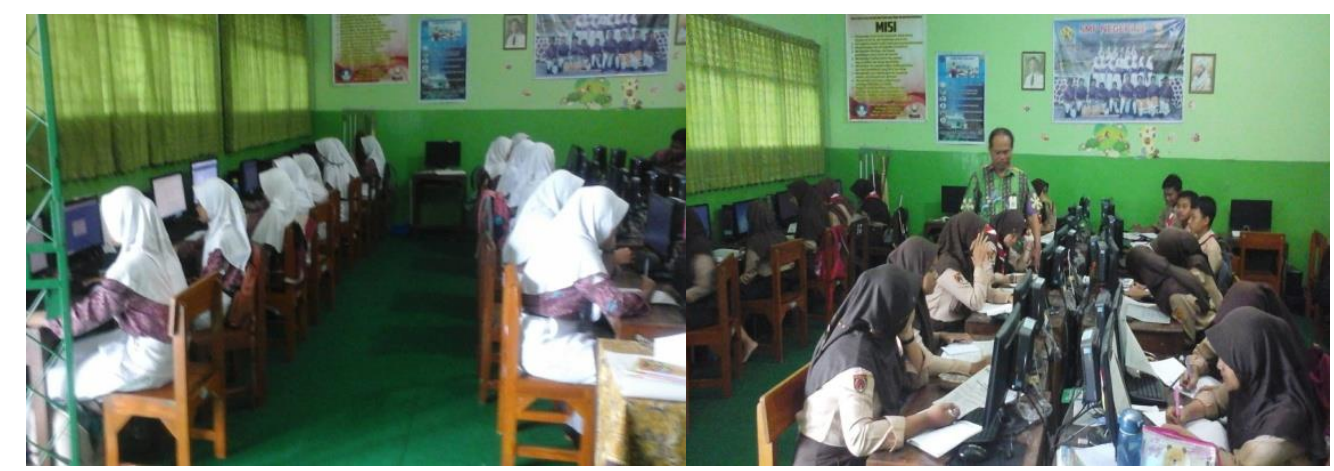

Gambar 2 Pembelajaran Siklus II

\section{Pembahasan}

\section{Hasil Belajar}

Menurut Nana Sudjana (2006: 22) menyatakan bahwa hasil belajar adalah kemampuan-kemampuan yang dimiliki siswa setelah ia menerima pengalaman belajarnya. Dalam system pendidikan nasional dirumuskan tujuan pendidikan baik tujuan kurikulum maupun tujuan pembelajaran, menggunakan klasifikasi hasil belajar dari Benyamin Bloom yang secara garis besar membaginya menjadi tiga ranah yakni kognitif, efektif, dan psikomotoris (Nana Sudjana, 2006: 22-23) 
Penguasaan terhadap konsep pada proses pembelajaran tersebut dapat dilihat pada penilaian evaluasi siswa. Pada siklus II dikatakan bahwa hasil belajar meningkat dibandingkan siklus I. Peningkatan tersebut dapat kita lihat pada tabel berikut ini.

Tabel 5 Persentase ketuntasan nilai Matematika kelas IXB Siklus I dan II

\begin{tabular}{|c|c|c|c|}
\hline No & Keterangan & Siklus I & Siklus II \\
\hline 1 & Rata-rata & 65,32 & 76,13 \\
\hline 2 & Persentase Ketuntasan & $52 \%$ & $87 \%$ \\
\hline 3 & Persentase ketidaktuntasan & $48 \%$ & $13 \%$ \\
\hline
\end{tabular}

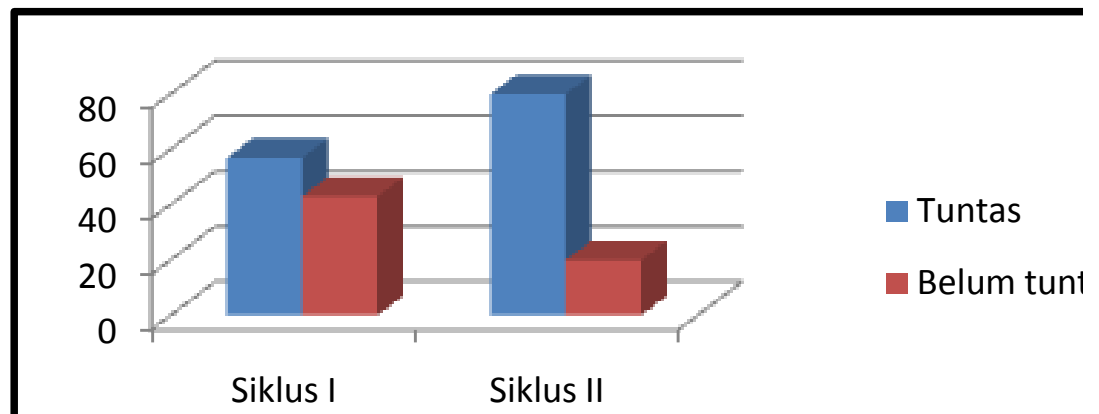

Grafik 3. Ketuntasan Hasil Belajar Siklus I dan II

Berdasarkan tabel dan grafik di atas menunjukkan bahwa hasil belajar siswa mengalami peningkatan. Ketuntasan belajar secara klasikal pada siklus I, dan siklus II dari 16 siswa (52\%) menjadi 27 siswa (87\%), sedangkan tidak tuntas 15 siswa (48\%) menjadi 4 siswa (13\%). Sebanyak 4 siswa yang tidak tuntas tersebut dikonsultasikan kepada guru bimbingan konseling untuk dicarikan solusi apakah siswa tersebut perlu diremidi atau kesulitan tidak bisa menerima pembelajaran model Think Pair Share ( TPS )berbantuan komputer.

Peningkatan hasil belajar pada siklus II ini disebabkan oleh penggunaan model pembelajaran Think Pair Shareberbantuan komputer yang berhasil, dan pembelajaran lebih bermakna, pengelolaan kelas dengan diskusi kelompok sesuai kedekatan pertemanan siswa melnyebabkan keaktifan lebih tinggi.

Dengan terpenuhinya indikator keberhasilan lebih dari $75 \%$ yang diperoleh siswa kelas IXB SMPN 26 Semarang tahun pelajaran 2019/2020. Dengan demikian apa yang menjadi tujuan sudah terpenuhi dan dapat dikatakan berhasil.

\section{Hasil Keaktifan Siswa}

Pengkajian data yang peneliti lakukan pada proses pembelajaran siklus I, dan siklus II, secara bertahap mengalami peningkatan yang lebih baik. Hal ini dapat kita lihat pada tabel berikut. 
Tabel 6. Persentase Peningkatan Keaktifan Siswa Siklus I dan II

\begin{tabular}{|c|c|c|c|c|}
\hline \multirow{2}{*}{} & \multicolumn{2}{|c|}{ Siklus I } & \multicolumn{2}{c|}{ Siklus II } \\
\cline { 2 - 5 } & Banyaknya Siswa & Persentase & $\begin{array}{c}\text { Banyaknya } \\
\text { Siswa }\end{array}$ & Persentase \\
\hline Tingkat Keaktifan & 31 & $66 \%$ & 31 & $76 \%$ \\
\hline
\end{tabular}

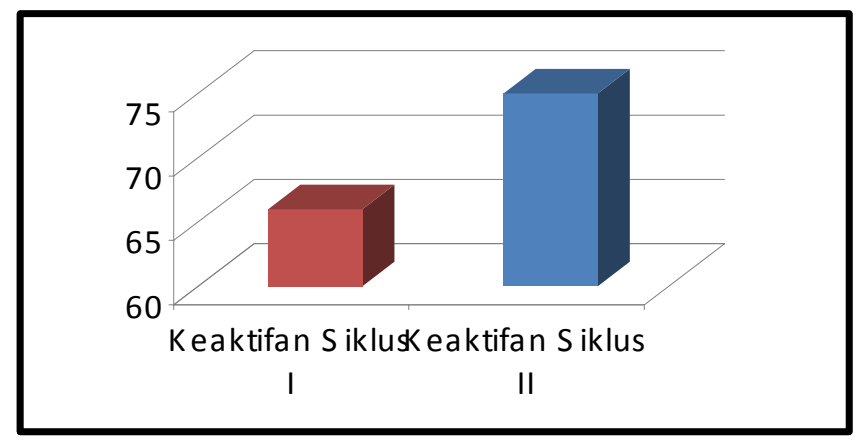

Grafik 4. Keaktifan Siswa Siklus I dan II

Dari data tabel dan grafik tersebut di atas, maka dapat diperoleh informasi bahwa keaktifan siswa pada siklus II meningkat, yang semula pada siklus I keaktifan siswa saat melakukan kerjasama hanya $66 \%$ pada siklus II menjadi $76 \%$. Hal ini disebabkan perkembangan mental siswa tersebut berbeda dari siswa secara normal lainnya.

Dalam setiap proses belajar, siswa selalu menampakkan keaktifan. Kegiatan itu beraneka ragam bentuknya, mulai dari kegiatan fisik yang mudah kita amati sampai kegiatan psikis yang susah diamati. Kegiatan fisik berupa membaca, mendengar, menulis, berlatih keterampilan-keterampilan dan sebagainya. Dengan menggunakan khasanah pengetahuan yang dimiliki dalam membandingkan satu konsep dengan kata lain, menyimpulkan hasil dan kegiatan psikis yang lain.

Penerapan model pembelajaran Think Pair Shareberbantuan komputer yang peneliti lakukan tentunya lebih memunculkan keaktifan intrinsik siswa dan dengan penerapan model pembelajaran Think Pair Share berbantuan komputer dapat meningkatkan hasil belajar siswa. Dengan demikian penerapan strategi pembelajaran berhasil.

\section{Kesimpulan}

Berdasarkan analisis data pada bahasan sebelumnya serta hasil Penelitian Tindakan Kelas yang dilakukan, maka peneliti menarik simpulan sebagai berikut: 
1. Penerapan model pembelajaran Think Pair Share berbantuan komputerdapat meningkatkan hasil belajar matematika materi persamaan kuadrat bagi siswa kelas IXB SMPN 26 Semarang. Peningkatan hasil belajar tersebut dibuktikan dengan ketuntasan hasil belajar siswa. Jika pada pada silkus I ketuntasan klasikal 52\% rata-rata 65,32, kemudian pada siklus II meningkat menjadi $87 \%$ rata-rata 76,13 .

2. Penerapan model pembelajaran Think Pair Share berbantuan komputer dapat meningkatkan keaktifan siswa kelas IXB SMPN 26 Semarang. Hal ini dibuktikan dengan lembar pengamatan keaktifan siswa siklus I yaitu 66\% katagori cukup, kemudian siklus II menjadi $76 \%$ katagori tinggi.

\section{Saran}

Berdasarkan hasil uraian di atas, dapat dikemukakan saran sebagai berikut.

1. Sebagai tindak lanjut dari penelitian tindakan kelas ini perlu adanya penelitian tindakan kelas lanjutan mengenai penerapan model Think Pair Share berbantuan komputer pada materi lain .

2. Berdasarkan hasil penelitian ini guru kelas IX sebaiknya pada saat pembelajaran matematika dapat menerapakan model Think Pair Share berbantuan komputer, karena dengan mengkondisikan siswa dengan situasi yang menyenangkan akan membuat materi pelajaran matematika mudah diterima siswa.Pihak sekolah selalu mendorong guru-guru untuk melakukan penelitian tindakan kelas untuk meningkatkan profesionalisme guru.

\section{Pustaka}

Arikunto, Suharsimi.2006. ProsedurPenelitian Suatu Pendekatan Praktek Edisi Revisi VI. Jakarta: Rineka Cipta.

Arikunto, Suharsimi, dkk. 2008. Penelitian Tindakan Kelas. Jakarta: Bumi Aksara.

Anderson, R.H.. 1987. Pemilihan dan Pengembangan Media untukPembelajaran. Jakarta: Rajawali Pers.

Suharjo. 1994. Penggunaan Komputer dalam Pengajaran. Sumber Belajar.

I (1):43-53.

Sudjana, Nana. 2006. Penilaian Hasil Belajar Mengajar. Bandung : PT Remaja Rosdakarya

Subchan dkk..2018. Buku Siswa Matematika kelas IX. Jakarta: Penerbit Kemendikbud.

Syah, Muhibin. 2002. Psikologi Belajar. Bandung : Raja Grafindo Persada.

W. Gulo. 2002. Strategi Belajar Mengajar. Jakarta: Grasindo. 
$\delta$ ELT $\Delta$ Jurnal Ilmiah Pendidikan Matematika

Trianto. 2007.Model-Model Pembelajaran Inovatif Berorientasi Konstruktivistik. Jakarta: Prestasi Pustaka.

Zaini, Hisyam dkk. 2007. Strategi Pembelajaran Aktif. Yogyakarta: CTSD. 